\title{
The Relationship between Knowledge Management, Emotional Intelligence and Empowerment to Performance
}

\author{
Jamrizal, Billy Tunas, M. Entang \\ Post Graduate Program, Universitas Pakuan Bogor, Indonesia
}

\begin{abstract}
The aim of this study is to examine the influence of Knowledge Management, Emotional Intelligence and Empowerment to Performance either individually or simultaneously. Variables of Knowledge Management, Emotional Intelligence and Empowerment function as independent variables while the dependent variable is Performance. The research was conducted on proportional randomly selected 119 principals of private Islamic Junior High schools in Jambi Province, Indonesia. Using mix method, sequential explanatory design is applied where quantitative comes first. The study both quantitatively and qualitatively reveals that there is a positive significant relationship among variables under the following distribution of coefficient of correlation: Knowledge Management to principal's performance $=0.181$, Emotional Intelligence to principal's performance $=0.585$, Empowerment to principal's performance $=0.565$ and when tested together it produces coefficient of determination $=0.397$ indicating the existence of other $60.3 \%$ variables not including in the model affecting principal's performance within the Islamic Junior High schools principals'working environment.
\end{abstract}

Keywords: Knowledge Management, Emotional Intelligence, Empowerment, Performance

\section{INTRODUCTION}

The successful formation and development of quality human resources is very dependent on the synergies between citizens and the schools. The existence of the role and function of the principal is one of the factors that determine the quality of Islamic Junior High schools. Headmaster must have competence in leading in order to create a comfortable working environment, pleasant learning atmosphere, excellent service, and managerial balanced management. Principals are responsible for institution in carrying out activities, managing the various problems associated with the administration, maintaining facilities and infrastructure to perform well reflected in possession of sufficient competencies. Headmaster is one important component in the process of achieving goals so he should be able to stimulate and guide teachers continuously to perform better in all teaching duties so that they are finally able to stimulate and guide students to be able to participate in society.

Performance of headmaster is one of the factors that encourage the school to realize the vision, mission, goals and objectives through a planned program. Headmaster in charge of education and learning at the school should be able to convince the public that everything has gone well, including the planning and implementation of curriculum, provision and teacher resource, recruitment of pupil, establishing cooperation between school and parents, as well as the figure to position the school as a prospective one. Therefore, as a headmaster should be able to communicate well with all elements in order to realize the vision, mission, goals and objectives of the Islamic Junior High schools.

Based on the results of a preliminary survey of the 20 votes against the Head of Private Islamic Junior High schools, it is obtained an overview of the performance which is still low. From the survey data we concluded as follows:

1. Percentage of Principals who does not carry out the duties and functions aspects reached 66\%;

2. Percentage of Principals that has not been able to demonstrate aspects of commitment to the task reached $23.73 \%$;

3. Percentage of Principals who has not been able to demonstrate aspects of the work reached $65.00 \%$.

Based on the preliminary survey data above, it can be concluded that the performance conditions of principals the respective schools still low and needs to be improved. However, the increase referring 
to improving the performance particularly requires time for dealing with the various factors involved. Such factors include Knowledge Management, Emotional Intelligence, Empowerment and so forth. Based on the background and restriction issues to be examined in this study, it can be formulated main points as follows:

1. Is there a relationship between Knowledge Management, with Performance?

2. Is there a relationship between Emotional Intelligence with teacher Performance?

3. Is there a relationship between Empowerment with Performance?

4. Is there a relationship between Knowledge Management, Emotional Intelligence and Empowerment simultaneously with the teacher's performance?

\section{LiterATURE REVIEW}

Performance is defined by Colquitt, J.A, Lepine and Wesson (2009) as the value of the set behavior of someone who contributes, either positively or negatively, to the achievement of organizational goals. This definition includes behavior without control, but still within the limits of the relevant behavior, not on job performance. In general, behaviors that can be divided into three categories: behavior in performing the task, the behavior as citizens and unproductive behavior that contributed negatively to the organization.

Newstrom (2008) states that "performance is satisfactory feedback enhancing employee's self-image and feeling of competence. Performance feedback leads to both improved performance and improved attitude. Performance feedback leads to improvements in performance and changes in attitudes.

Rue and Byars (2007) defines performance refers to how well a teacher in meeting the requirements of the job determined by three main factors, namely: effort, ability and direction. These three factors mentioned above certainly has a direct causal effect; because they are interrelated. If one factor is not owned by a teacher, the performance will be low.

James L. Gibson et.al (2003) defines that a person's performance will be crucial for the performance of the organization. The performance of the individual is the basis for the performance of the organization, the higher the performance of the individual, the higher the achievement of organizational performance.

Based on existing theoretical studies, it can be synthesized, that the performance is the performance of teachers in carrying out the tasks assigned reflected in the output produced good quality of quantity. As for the indicators that show the performance of teachers is (A).Lesson plans; (B) The implementation of learning; (C)Evaluation of learning; (D) Following up the results of the evaluation, and (E) Of interpersonal communication.

Knowledge management (KM) is the process of creating, sharing, using and managing the knowledge and information of an organization (Girard, 2015). It refers to a multidisciplinary approach to achieving organisational objectives by making the best use of knowledge. Knowledge management efforts typically focus on organisational objectives such as improved performance, competitive advantage, innovation, the sharing of lessons learned, integration and continuous improvement of the organisation. These efforts overlap with organisational learning and may be distinguished from that by a greater focus on the management of knowledge as a strategic asset and on encouraging the sharing of knowledge. KM is an enabler of organisational learning (Gupta, et.al, 2004). The process of knowledge management begins with the identification and classification of the types of the knowledge which currently exist in the organization followed by the understanding of where and how the knowledge exists (Hislop, 2013). The systematic process of finding, selecting, organizing, distilling and presenting information in a way that improves an employee's comprehension in a specific area of interest.

Emotional intelligence (EI) is the capability of individuals to recognize their own, and other people's emotions, to discern between different feelings and label them appropriately, to use emotional information to guide thinking and behavior, and to manage and/or adjust emotions to adapt environments or achieve one's goal (Coleman, 2007). Research of EI and job performance shows mixed results: a positive relation has been found in some of the studies, while in others there was no relation or an inconsistent one. This led researchers Cote and Miners (2006) to offer a compensatory model between EI and IQ, that posits that the association between EI and job performance becomes 
more positive as cognitive intelligence decreases, an idea first proposed in the context of academic performance (Petrides, \& Furnham, 2001). The results of the former study supported the compensatory model: employees with low IQ get higher task performance and organizational citizenship behavior directed at the organization, the higher their EI. It has also been observed that there is no significant link between emotional intelligence and work attitude behavior.

The term empowerment refers to measures designed to increase the degree of autonomy and selfdetermination in people and in communities in order to enable them to represent their interests in a responsible and self-determined way, acting on their own authority. Empowerment as action refers both to the process of self-empowerment and to professional support of people, which enables them to overcome their sense of powerlessness and lack of influence, and to recognize and use their resources (Fetterman, \& Wandersman, 2005). In the sphere of management and organizational theory, "empowerment" often refers loosely to processes for giving subordinates (or workers generally) greater discretion and resources: distributing control in order to better serve both customers and the interests of employing organizations.

Empowerment of employees requires a culture of trust in the organization and an appropriate information and communication system. The aim of these activities is to save control costs that become redundant when employees act independently and in a self-motivated fashion. In the book Empowerment Takes More Than a Minute, the authors illustrate three keys that organizations can use to open the knowledge, experience, and motivation power that people already have (Hur, 2006). The three keys that managers must use to empower their employees are:

1. Share information with everyone

2. Create autonomy through boundaries

3. Replace the old hierarchy with self-managed teams

According to Stewart (1994) in order to guarantee a successful work environment, managers need to exercise the "right kind of authority". To summarize, "empowerment is simply the effective use of a manager's authority", and subsequently, it is a productive way to maximize all-around work efficiency.

Based on the study of theory and framework as described above, the following hypothesis is formulated:

1. There is a positive relationship between knowledge management with principal's performance.

2. There is a positive relationship between emotional intelligence with principal's performance.

3. There is a positive relationship between empowerment and principal's performance.

4. There is a positive relationship between knowledge management, emotional intelligence and empowerment simultaneously with the performance of principal.

\section{Methodology}

This study applies Sequential Explanatory Design Mixed Method where quantiative study is ahead of qualitative study to examine the relationship between variables tested in the study using three independent variables through data obtained from questionnaires. The independent variable is knowledge management $\left(\mathrm{X}_{1}\right)$, emotional intelligence $\left(\mathrm{X}_{2}\right)$, and empowerment $\left(\mathrm{X}_{3}\right)$, while the dependent variable is the principal's performance (Y).

The relationship among variables in the study described in Fig.1 below:

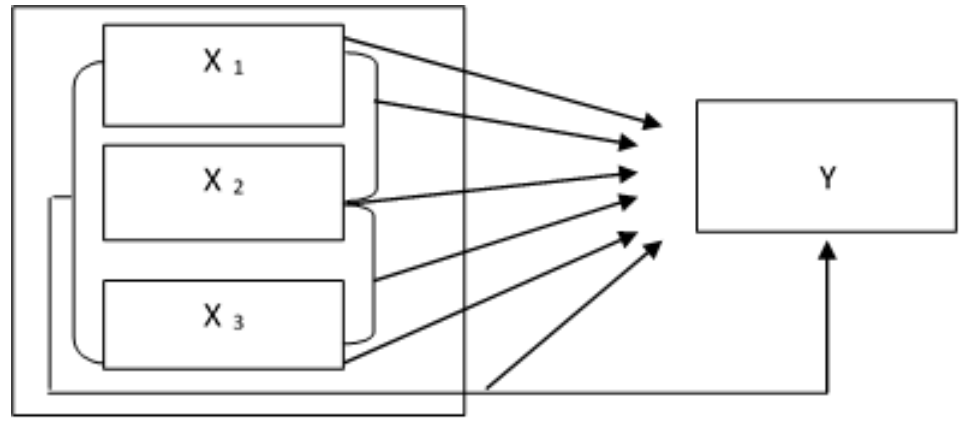

Figure1. Theoretical Framework 
where,

$\mathrm{Y}=$ principal's performance.

$\mathrm{X}_{1}=$ knowledge management

$\mathrm{X}_{2}=$ emotional intelligence

$\mathrm{X}_{3}=$ empowerment

The sampling technique is to count the number of samples by using the Slovin's formula generating samples obtained as many as 119 respondents out of 168 teachers. Hypothesis testing is conducted by using regression analysis to determine the influence of one or more independent variables on the dependent variable. The normality assumption with Liliefors test are prerequisites to proceed to further test. Hypothesis testing is performed at a significance level of 0.05 .

Qualitative study for the purpose of confirmation was performed through observation and interview to key informant as well as conducting focus group discussion with school principal and teachers.

\section{RESUlt AND DISCUSSION}

The teachers of listed organisations were asked to participate in the survey by responding their opinions for four different measures in Knowledge Management, Emotional Intelligence, Empowerment and Principal's Performance. Data is normal as the value of each variable $=0.0738,0.0797$, 0.0741 below the critical value Liliefors test for $\mathrm{N}=119$ which is 0.0812 .

\subsection{Knowledge Management and Principal's Performance}

Since the data is normally distributed, we can proceed to test the alternate hypothesis if Knowledge Management is positively related to Principal's performance within private Islamic junior high school organisations in Jambi, Indonesia. The strength of association of Knowledge Management $\left(\mathrm{X}_{1}\right)$ to Principal' performance $(\mathrm{Y})$ is observable from coefficient correlation $\left(\mathrm{r}_{\mathrm{x} 1}\right)=0.219$. $\mathrm{T}_{\text {test }}=3.156$ is above critical value where $T_{\text {-tabel }}$ for $(\alpha=0.05)$ is 1.645 indicating that the relationship is significant confirming the first hypothesis that Knowledge Management is positively related to Principal' performance. Coefficient of determination $\left(\mathrm{r}_{\mathrm{x}}^{2} 1\right)=0.048$ indicates that contribution of Knowledge Management to Principal' performance is only $4.8 \%$.

Similarly, result of qualitative research interviews, observation and documentation confirms the tendency of the relationship between Knowledge Management to Principal' performance. This finding strengthens the quantitative research hypothesis results testing that there is a positive significant relationship between Knowledge Management to Principal' performance.

This finding is in line with Kosasih \& Budiani (2008) who found out that knowledge management efforts which typically focus on organisational objectives such as improved performance, competitive advantage, innovation, the sharing of lessons learned, integration and continuous improvement of the organization has significant impact on performance.

\subsection{Emotional Intelligence and Principal' Performance}

Since the data is normally distributed, we can proceed to test the alternate hypothesis if Emotional Intelligence is positively related to Principal's performance within private Islamic junior high school organisations in Jambi, Indonesia. The strength of association of Emotional Intelligence $\left(\mathrm{X}_{2}\right)$ to Principal' performance $(Y)$ is observable from coefficient correlation $\left(r_{x 2}\right)=0.585$. $T_{\text {test }}=7.870$ is above critical value where $T_{\text {-tabel }}$ for $(\alpha=0.05)$ is 1.645 indicating that the relationship is significant confirming the second hypothesis that Emotional Intelligence is positively related to Principal' performance. Coefficient of determination $\left(\mathrm{r}_{\mathrm{x} 2}^{2}\right)=0.342$ indicates that contribution of Emotional Intelligence to Principal' performance is $34.2 \%$.

Similarly, result of qualitative research interviews, observation and documentation confirms the tendency of the relationship between Emotional Intelligence to Principal' performance. This finding strengthens the quantitative research hypothesis results testing that there is a positive significant relationship between Emotional Intelligence to Principal' performance.

This finding is in line with Fitriastuti, (2013) who found out that Emotional intelligence (EI) is the capability of individuals to recognize their own, and other people's emotions, to discern between 
different feelings and label them appropriately, to use emotional information to guide thinking and behavior, and to manage and/or adjust emotions to adapt environments or achieve one's goal has significant impact on performance.

\subsection{Empowerment and Principal's Performance}

Similar to previous model, as the data is normally distributed, we can proceed to test the alternate hypothesis if Empowerment is positively related to Principal's performance within private Islamic junior high school organisations in Jambi, Indonesia. The strength of association of Empowerment $\left(\mathrm{X}_{3}\right)$ to Principal' performance $(\mathrm{Y})$ is observable from coefficient correlation $\left(\mathrm{r}_{\mathrm{x} 3}\right)=0.565$. $\mathrm{T}_{\text {test }}=$ 7.870 is above critical value where $T_{\text {tabel }}$ for $(\alpha=0.05)$ is 1.645 indicating that the relationship is significant confirming the third hypothesis that Empowerment is positively related to Principal' performance. Coefficient of determination $\left(\mathrm{r}^{2}{ }_{\mathrm{x} 2}\right)=0.319$ indicates that contribution of Empowerment to Principal' performance is $31.9 \%$.

Similarly, result of qualitative research interviews, observation and documentation confirms the tendency of the relationship between Empowerment to Principal' performance. This finding strengthens the quantitative research hypothesis results testing that there is a positive significant relationship between Empowerment to Principal' performance.

This finding is in line with Fadzilah (2006) who found out empowerment referring to measures designed to increase the degree of autonomy and self-determination in people and in communities in order to enable them to represent their interests in a responsible and self-determined way, acting on their own authority. Empowerment as action refers both to the process of self-empowerment and to professional support of people, which enables them to overcome their sense of powerlessness and lack of influence, and to recognize and use their resources has significant impact on performance.

\subsection{Knowledge Management, Emotional Intelligence and Empowerment to Principal's Performance}

The functional relationship between knowledge management, emotional intelligence and empowerent together with performance of the headmaster generates regression equation $\mathrm{Y}=43.195+0.488 \mathrm{X} 1$ $+0.341 \mathrm{X} 2+0.255 \mathrm{X} 3$ with a value of $\mathrm{F}=25.337$ exceeding the critical value of F-Table $(\alpha=0.01)=$ 3.9566 indicating that the regression is very significant. The value of multiple correlation coefficient of 0.6308 and coefficient of determination $=0.3979$ indicating that $39.79 \%$ of Principals' Performance in private Islamic Junior High School in Jambi Indonesia can be explained by the variables of knowledge management, emotional intelligence and empowerment.

The above results reinforced by the results of qualitative research that knowledge management, emotional intelligence and the empowerment affect the Principal's Performance in private Islamic Junior High School in Jambi Indonesia.

The findings of other factors that allegedly helped influence on the achievement of Principal's Performance in private Islamic Junior High School in Jambi Indonesia revealed through qualitative research are: 1) the of authorities of chief's foundation'2) policy, 3) social support and environment, 4) competence, 5) organizational culture, 6) entrepreneurial competencies, 7) school committee, 8) monitoring system, and 9) style of leadership.

\section{Conclusion}

The findings prove that there is a positive and significant relationship between knowledge management, on principal's performance, emotional intelligence on principal's performance, and empowerment on principal's performance among teachers working in private Islamic junior highs located in Jambi, Indonesia. With particular reference to initial design of the interaction among variables, the results showed that the contribution of knowledge management variable on performance is $4.8 \%$, emotional intelligence is $34.2 \%$, and empowerment is $31.9 \%$ indicating the highest individual contribution to the performance of principal is emotional intelligence. When combined together, contribution of the three variables of Knowledge Management, Emotional Intelligence and Empowerment achieve $39.79 \%$ indicating the contribution of other variables not included in the model to predict private Islamic junior high school teachers' performance are 60.21 $\%$. 


\section{REFERENCES}

Cote, S., \& Miners, C. T. (2006). Emotional intelligence, cognitive intelligence, and job performance. ADMINISTRATIVE SCIENCE QUARTERLY, 51(1), 1-28.

Coleman, Daniel, dkk, Prima Leadership Berdasarkan Emosi. Kepemimpinan Berdasarkan Kecerdasan Emosi. Terjemahan Rahayu Lestari. Jakarta: Gramedia Pustaka Utama., 2007;

Fadzilah, A. (2006). Analisis Pengaruh Pemberdayaan Karyawan dan Self of Efficacy Terhadap Kinerja Karyawan Bagian Penjualan (Studi Kasus Pada Pt. Sinar Sosro Wilayah Pemasaran Semarang). STUDI MANAJEMEN DAN ORGANISASI, 3(1), 12-27.

Fetterman, D. M., \& Wandersman, A. (Eds.). (2005). Empowerment evaluation principles in practice. Guilford Press.

Fitriastuti, T. (2013). Pengaruh Kecerdasan Emosional, Komitmen Organisasional Dan Organizational Citizenship Behavior Terhadap Kinerja Karyawan. Jurnal Dinamika Manajemen, 4(2).

Gibson. James L., John M. Ivancevich, and James H. Jr. Donnelly. Fundanmental of Management. Texas: Business Publications, Inc, 2003;

Girard, J., \& Girard, J. (2015). Defining knowledge management: Toward an applied compendium. Online Journal of Applied Knowledge Management, 3 (1), 1, 20.

Gupta, J. N., Sharma, S. K., \& Hsu, J. (2004). An overview of knowledge management. Creating knowledge based organizations, 360.

Hislop, D. (2013). Knowledge management in organizations: A critical introduction. Oxford University Press.

Hur, M. H. (2006). Empowerment in terms of theoretical perspectives: Exploring a typology of the process and components across disciplines. Journal of community psychology, 34(5), 523.

Kosasih, N., \& Budiani, S. (2008). Pengaruh knowledge management terhadap kinerja karyawan: studi kasus departement front office Surabaya plaza hotel. jurnal manajemen perhotelan, 3(2), 80-88.

Lepine Collquitt and Wesson. Organizational Behavior: Improving Performance and Commitment in the Workplace. (New York: Mc Graw-Hill Book Companies inc., 2009;

Newstrom John W, 2008. Organizational Behaviour: Human Behavior at Work New York: McGrawHill Inc., p: 140

Petrides, K.V., \& Furnham, A. Trait emotional intelligence: Psychometric investigation with reference to established trait taxonomies. European Journal of Personality, 15, 425-448., 2001;

Stewart, A. (1994). Empowerment and enablement: occupational therapy 2001. British Journal of Occupational Therapy, 57(7), 248-254. 